University of Wollongong

Research Online

Faculty of Law, Humanities and the Arts Papers (Archive)

Faculty of Arts, Social Sciences \& Humanities

$1-1-2018$

\#fear\&loathing in Sydney: Law, Justice and the Experience of Fear in a Hashtag World

Cassandra E. Sharp

University of Wollongong, csharp@uow.edu.au

Follow this and additional works at: https://ro.uow.edu.au/lhapapers

Part of the Arts and Humanities Commons, and the Law Commons

Research Online is the open access institutional repository for the University of Wollongong. For further information contact the UOW Library: research-pubs@uow.edu.au 


\title{
\#fear\&loathing in Sydney: Law, Justice and the Experience of Fear in a Hashtag World
}

\author{
Abstract \\ It is now commonplace for political discourse, news reports, and popular fictions to draw on themes of \\ political violence and threats to national and individual security as mechanisms for the perpetuation of \\ fear. Stories (whether fictive or factual) of terrorism, crisis, surveillance, racial stereotyping, and the \\ fallibility of law have become a very real part of the mediated experience of fear for the public, and they \\ provoke a number of questions surrounding complex issues of protectionism, identity, trust, and the \\ conflation of law and justice. It has been argued that such stories are constructed and utilized by key \\ decision-makers as effective politicking in order to promote protectionist policies and activities. In \\ recognizing that this "politics of fear" rests upon public assumptions and beliefs concerning safety and \\ risk, it is important to understand how a public experience of fear is actually expressed and constituted in \\ the public imaginary. Using social media as an interesting lens through which we can understand how \\ fear is defined and realized in everyday social interaction, the paper will demonstrate that in times of high \\ alert Twitter provides access to an articulated experience of fear. This paper will qualitatively explore the \\ co-production and (re)circulation of these assumptions and beliefs through one particular story: the \\ "Sydney Siege" hostage event of December 2014. By focusing on the Twitter response to this event, the \\ paper provides an empirical account of public critique of law's justice narrative through the emotional \\ experience and expression of fear. Drawing on critical content analysis and the Aristotelian discourse \\ analysis method, the paper illustrates the complicity of social media, emotion and a prevalent rhetoric of \\ fear in the reinforcement of law's justice narrative during times of high alert or crisis.

\section{Disciplines} \\ Arts and Humanities | Law

\section{Publication Details} \\ C. Sharp, '\#fear\&loathing in Sydney: Law, Justice and the Experience of Fear in a Hashtag World' (2018) 30 \\ (1) Law and Literature 29-52.
}




\section{Law \& Literature}

\section{\#fear\&loathing in Sydney: Law, Justice and the Experience of Fear in a Hashtag World}

\section{Cassandra Sharp}

To cite this article: Cassandra Sharp (2018) \#fear\&loathing in Sydney: Law, Justice and the Experience of Fear in a Hashtag World , Law \& Literature, 30:1, 29-52, DOI: 10.1080/1535685X.2017.1348577

To link to this article: https://doi.org/10.1080/1535685X.2017.1348577

\section{曲 Published online: 08 Nov 2017.}

Submit your article to this journal

LII Article views: 149

View Crossmark data $\asymp$ 


\title{
\#fear\&loathing in Sydney: Law, Justice and the Experience of Fear in a Hashtag World
}

\section{Cassandra Sharp}

\begin{abstract}
It is now commonplace for political discourse, news reports, and popular fictions to draw on themes of political violence and threats to national and individual security as mechanisms for the perpetuation of fear. Stories (whether fictive or factual) of terrorism, crisis, surveillance, racial stereotyping, and the fallibility of law have become a very real part of the mediated experience of fear for the public, and they provoke a number of questions surrounding complex issues of protectionism, identity, trust, and the conflation of law and justice. It has been argued that such stories are constructed and utilized by key decision-makers as effective politicking in order to promote protectionist policies and activities. In recognizing that this "politics of fear" rests upon public assumptions and beliefs concerning safety and risk, it is important to understand how a public experience of fear is actually expressed and constituted in the public imaginary. Using social media as an interesting lens through which we can understand how fear is defined and realized in everyday social interaction, the paper will demonstrate that in times of high alert Twitter provides access to an articulated experience of fear. This paper will qualitatively explore the co-production and (re)circulation of these assumptions and beliefs through one particular story: the "Sydney Siege" hostage event of December 2014. By focusing on the Twitter response to this event, the paper provides an empirical account of public critique of law's justice narrative through the emotional experience and expression of fear. Drawing on critical content analysis and the Aristotelian discourse analysis method, the paper illustrates the complicity of social media, emotion and a prevalent rhetoric of fear in the reinforcement of law's justice narrative during times of high alert or crisis.
\end{abstract}

Keywords, Twitter, social media, fear, rhetoric, Aristotle, vulnerability

Is it even safe to leave your home anymore? Can we as Australians walk freely down the street without the fear of terrorism? \#sydneysiege (@ItsMinaYo, December 14)

Fear is a powerful force that finds its way easily into our psyches. Consider the last time you might have encountered significant fear? What emotions were manifested,

Law \& Literature, VOL. 30, ISSUE 1, PP. 29-52. ISSN 1535-685X, ELECTRONIC ISSN 1541-2601. (c) 2017 by The Cardozo School of Law of Yeshiva University. All rights reserved. https://doi.org/10.1080/1535685X.2017.1348577. 
and what physical reactions did you have? Whatever the circumstances, an experience of fear is something with which most can identify. Yet, now consider whether it would be something about which you would express publicly online? Perhaps not if it were a truly personal experience of fear, but certainly, during times of high public alert or crisis, individuals are increasingly tweeting or posting an update about personal responses to these significant or distressing events. Living as we do within a contemporary landscape that includes various forms of participatory media, the cultural and communal experience and articulation of fear can easily dominate and captivate the public imaginary.

The comments cited above were posted on Twitter in response to the 2014 Sydney Siege hostage event. Over a period of two weeks, approximately 5.5 million tweets were posted with the hashtag "Sydneysiege" (\#sydneysiege). Similar to the examples above, contained within these tweets were the sound bites of fear, anger, and vulnerability, along with clear evidence that, individually and collectively, users were attempting to come to terms with this significant and tragic event. Not only this, but interwoven through this storied tapestry of public comment was an emotional critique of legality and justice that belied communal insecurity and apprehension. Despite the embeddedness of social media in "everyday social and communicative interactions," ${ }^{1}$ particularly during traumatic crisis events, little to no research has been done to explore empirically the public legal understanding generated by such events, or to explore how complex ideas of terror, fear and security are expressed in the discursive space offered by social media. This article seeks to fill that gap by providing a qualitative account of the role of public comment and conversation in perpetuating a rhetoric of fear - in particular, focusing on the coproduction and (re)circulation of everyday assumptions and beliefs through the story of a hostage event that came to be termed the "Sydney Siege." On Monday December 15, 2014, at 8.33am, a single gunman, Man Monis, took 17 people hostage in the Lindt Café in Martin Place, Central Sydney. It was a siege that lasted over 17 hours, and violently ended with police storming the building, the gunman being killed, and, tragically, the deaths of two hostages. During that time many of us will have "wondered how we would have reacted had we been trapped in the siege and faced" these circumstances, ${ }^{2}$ and it was easy to recognize the powerful work of fear as it moved its way easily into a collective consciousness.

The Sydney Siege was a dramatic local event viewed globally, and it seemed to engage emotions significantly through both mainstream and social media. Julie Posetti argues that the communication of traumatic crisis events like the Sydney Siege no longer relies "exclusively on mainstream media reporters bound by traditional publication deadlines," 3 but instead, the prolific activity of social media now ensures that local coverage "unfolds instantly in an international context." And so on December 15, it seemed that global eyes had turned their attention to this heartbreaking event as it unfolded. Social media platforms became hyperactive, with voyeurism transformed into dynamic conversation that responded in real time to each 
development as it was reported by both mainstream media and citizen journalists. Saturating what became a natural outpouring of anguish, anger, resentment, and grief was a concentrated rhetoric of fear containing comments about Islamic extremists and questions about individual and national security. Twitter, of course, was no exception. The focus of this article is to analyze the comments uploaded to Twitter in response to this event as a way of empirically exploring a collective expression of fear. As such, the next section of the article will briefly comment of the rhetoric of fear, while the third section will contextualize the use of critical content analysis and the Aristotelian discourse analysis method for analyzing social media. The fourth section will then illustrate the complicity of social media and emotion in simultaneously perpetuating, and critiquing, law's narrative of justice.

\section{THE RHETORIC OF “FEAR"}

The culture of fear has existed long before the "War on Terror" became a ubiquitous term, ${ }^{5}$ with its defining feature being a belief that "humanity [will often be] confronted by powerful destructive forces that threaten our everyday existence." Although not all these have been associated with crime (financial destruction, pandemic viruses, global warming, and the sustainability of the Earth), a culture of fear does seem to be heavily associated with criminal activity. ${ }^{7}$ But since $9 / 11$, a particular culture of fear, within the context of terror, has become a characteristic aspect of everyday discourse, ${ }^{8}$ where it seems natural to have a "fatalistic sensibility" when it comes to terrorism and its related activities. This is a "not if, but when" sensibility to life that "co-exists with anxieties concerning the future," and this in turn has the potential to predispose the public to feelings of discomfort managing the various uncertainties of life. ${ }^{10}$

It is these anxieties that are persuasively utilized by key decision-makers as effective politicking in order to promote protectionist policies and activities, and to "whip up aggression against unpopular groups." ${ }^{11}$ As Martha Nussbaum argues:

Our time is genuinely dangerous. As we have seen, many fears are rational, and appeals to fear have a role to play in a society that takes human life seriously. Still, at this point, the balance has all too often shifted in the other direction, as irresponsibly manufactured fears threaten principles we should cling to and be proud of. ${ }^{12}$

This shifting of balance contributes to the "politics of fear," which is understood as the method by which politicians manufacture fears to manipulate public anxieties in order to promote agendas. ${ }^{13}$ It is argued that the politics of fear is able to be so successful because it rests upon public assumptions about danger, risk, and uncertainty that already exist within our contemporary views of the world. It is these assumptions, then, "buffered by news and popular culture stressing fear and 
threat as features of entertainment,"14 that help to facilitate a rhetoric of fear. By rhetoric of fear, I am referring to the prevailing and repetitive interactions shaping public expectation that danger, risk, and crisis are normalized within everyday life. In times of heightened alert or crisis, the major impact of this type of rhetoric is the promotion of a sense of disorder and lack of control. ${ }^{15}$ In a culture that has institutionalized fear of a Hobbesian "unknowable harm," 16 this rhetoric easily preconditions the community to fear. As Brian Massumi contends, a "threat is only a threat if it retains an indeterminacy." 17 This integration of fear within our normative assumptions and expectations of everyday life subsequently impacts upon the way we respond to, interpret, and discuss events of significance. This impact is reflected in a heightened public awareness of crime, terrorism, crisis, and the "securing of the nation's urban spaces,"18 and, as we will see, the perpetuation of self-fulfilling fearful communication. For this reason, it is crucial to understand how a public experience of fear is indeed expressed and constituted in the public imaginary.

\section{TWITTER AND ARISTOTLE - EMOTION IN 140 CHARACTERS OR FEWER}

Social media ${ }^{19}$ "is the next iterative step in [the] history of communications. It combines the broad reach of broadcast media with the interactive nature of interpersonal communications," ${ }^{20}$ and as an extremely open "public forum, the internet provides an unprecedented opportunity to share ideas on a global scale. It is userfriendly, [...] and most importantly, it is both accessible and mainstream [... with] the potential to engage an enormous audience." ${ }^{21}$ Indeed, it has been suggested that social media sites "are now bigger and more powerful than some nation states [... and that these] sites [are] powerful influencers of public opinion and thought."22 Consider how many you might have accessed in the last week? Could you go an entire day without accessing Facebook, Twitter, LinkedIn, Instagram, Vimeo, YouTube, Blogspot, Snapchat, Flickr, Tumblr, Google Plus, or Pinterest? Using social media is immensely popular and part of everyday interactions, ${ }^{23}$ and with $72 \%$ of all internet users now active on social media, widespread use has meant that many members of the public are no longer simply news consumers but are news participators ${ }^{24}$ "citizen journalists, citizen detectives, and even cyber vigilantes [...]." ${ }^{25} \mathrm{By}$ posting or reposting, tweeting or retweeting, headlines, links to news stories, and personal opinions or responses to a breaking issue, the platforms of social media become vital mechanisms through which the public not only can make sense of the world but also express their expectations of that world. For cultural legal scholars, social media platforms are further sites of reproduction, reflection, and resistance of the ideological anxieties and predicaments typical in contemporary society, and they can provide an alternate method of exploring conceptions of law as a justice institution.

Twitter, as one of those sites, has over 550 million registered users. It "is a medium of immediacy, information, and interactivity" 26 that opens up another 
method by which publics can "engage with the cultural, social and political realities with which they are confronted." ${ }^{27}$ It is an avenue through which individuals can "communicate and interact with the occurrences around them," 28 and is a unique mode of information dissemination, citizen journalism, and opinion expression. The Twitter platform invites and allows for the characterization of everyday lives around assumptions and beliefs about safety and danger, freedom and control, and protection and vulnerability.

Yet, because an individual is only permitted to use 140 characters in every tweet, Twitter has "changed the concept of how people [...] respond" 29 to major societal events. The limited number of characters creates a "constant stream of information in one's Twitter feed,"30 and can be quickly disseminated, retrieved, and reexperienced in perpetuity. ${ }^{31}$ Indeed, it has been argued that "the public, rather than professional journalists are increasingly recording the first draft of history" 32 and so in times of heightened alert of crisis, it is interesting and important to explore the ways that individuals will contribute to a collective narrative surrounding issues of law and justice in response to these events.

\section{Stories in a hashtag?}

The categorization of Tweets using the hashtag symbol (\#) combined with a keyword facilitates the creation of narratives surrounding current events and public issues. ${ }^{33}$ When clicking on a hashtag word in any message you can view all the other Tweets marked with that keyword, and you can see the development over time of a particular story arc. It is fascinating that this utilization of hashtags within tweets reflects our communal drive to narrativize the experiences of our world - "we can't help ourselves"; we interpret our lives through stories. ${ }^{34}$ This is consistent with my previous argument that individuals deploy stories in order to frame and contextualize normative expectations of the legal system. ${ }^{35}$ Moreover, in the (re)telling of stories, individuals verbalize and render apparent that which is often omitted from traditional accounts of law, such as the emotions, desires, and conflicting impulses "that circulate within the law." ${ }^{6}$ Indeed, the last couple of decades have seen an increasing recognition that embracing "an explicit role for emotion in law is an inherently normative enterprise." 37 This jurisprudence of emotion suggests that it is both undesirable and impossible to exclude emotion from legal analysis and calls for the exploration of legal meaning through emotions or affect as equally as other cognitive and rational functionalities. ${ }^{38}$

In this article, I take up that challenge and argue that through the platform of Twitter, legal meaning is constituted, transformed, and propagated through storied emotional responses to crisis events. These stories are collectively formed by the individual contributions of the users themselves as they create and then deploy hashtags in their comments. 
The Sydney Siege hashtag (\#sydneysiege) generated more than 600,000 tweets in just two days. Not only did mainstream news outlets use this hashtag to provide real-time updates, but also individuals were providing a constant stream of opinions and responses to the event, in effect narrativizing it. It was, in one way, an outlet for many to make sense of the event as it was occurring, and it was also an opportunity to articulate reactions that might be shared by others in the community. The tweets allowed for the retelling of the story through an emotional articulation of comments, and the conversation both extended and transformed the rhetoric concerning law's narrative of justice.

\section{Coding pathos in a hashtag}

With approximately 600,000 tweets $^{39}$ available during this time, the methodology deployed was a "virtual ethnography" 40 that facilitated immersion in the social setting of a trending Twitter hashtag occurring during those two days of heightened threat and fear. By using search criteria, the dataset was reduced, however, to a more manageable 1456 tweets. ${ }^{41}$ This dataset was then independently coded by myself and a research assistant according to categories established from a mixture of critical content analysis and Aristotelian rhetorical analysis. ${ }^{42}$ With tweets now being recognized as the "new sound bites" of media that have significant rhetorical impact, ${ }^{43}$ I found it useful to track the deployment of Aristotle's pathos as an expression of the experience of fear. Aristotle argued that pathos is a distinct persuasive appeal used to communicate everyday messages. ${ }^{44}$ It is an appeal to the audience's emotions in order to influence listeners by eliciting various emotional responses, such as fear, anger, and contempt, ${ }^{45}$ and it petitions the audience's sense of communal identity through the deployment of emotion in language. An enduring rhetoric of fear depends on the persuasive force of pathos in public conversation for its perpetuation, dominance, and longevity. The emotion of fear is elicited not solely by the situation or crisis event itself (although that is a significant factor), but also by (and within) the commonly shared responses to that particular event.

The key objective for this study was to provide an account of how emotional livetweets during a crisis might show the connection between emotion, stories, and public critique of legality and justice. As such, I applied coding categories that exposed the variances in the use of pathos contained in these 1456 tweets. This involved: coding against statements that expressed an appraisal of threat, danger, or vulnerability; coding expressions of what I termed "empathetic incongruence"; 46 coding those statements that belied uncertainty around coping; and coding those expressions that attributed blame through anger. ${ }^{47} \mathrm{~A}$ major crisis event such as the Sydney Siege has the potential to bring communities together around a particular shared passion - about issues of identity, vulnerability, and justice. Twitter not only feeds on this but also becomes a facilitator of this newly created common 
ground and easily allows for the sharing of identity and community building, through the communal grief, suffering, and general experience of calamity.

In the analysis, I found that by articulating their emotional response to the events as they happened in the Sydney Siege, members of the public contributed to the construction of several narratives. These were expressed through the sharing of identity as a vulnerable public, and the resultant shared comments of anger, concern, and grief that, in turn, both provoked and resisted the rhetoric of fear. Importantly, as will be illustrated below, interwoven through this storied tapestry of public comment was an emotional critique of legality and justice.

\section{TWITTER ANALYSIS}

Along these lines, this section provides an account of two connected narratives that emerged from the analysis: (1) that the rhetoric of fear engages key emotional appraisals that reinforces public belief in a just world; and (2) that the desire to resist fear mongering is activated through an implicit yearning to maintain that just world.

\section{"Just" worldview}

Post-9/11 we seem to live in a world that is increasingly dangerous and uncertain. It is one often filled with people and events that cause disorder and chaos, and so is therefore comprised of only friends or enemies. Australians, in particular, have been positioned for many years to witness the distant suffering of the terrorist attacks in other lands, and to be acutely aware that "we too are vulnerable to acts of terrorism." 48 This worldview incorporates a narrative whereby we are in continuous need of protection from our enemies by the law that exists in order to maintain a stable, just, and secure political and social environment. ${ }^{49}$ It is a narrative that scholars argue is cultivated and protected by governments in order to legitimize their actions (and indeed existence):

governments have declared a seemingly never ending war on terror. In reality, what they are doing is establishing the basis for a neverending state of fear, where supposedly only those in power have the ability to keep people safe and secure. ${ }^{50}$

As such this narrative emphasizes the important role that a "need" for a protective justice system plays in the life of law. Theories of human behavior in social psychology have long identified justice as a core desire for people that is implemented and protected by the law. The "belief in a just world," as articulated by Melvin Lerner ${ }^{51}$ reflects that people have a strong desire to live in a fair world where people 
get what they deserve and deserve what they get, and it involves "the assumptions by which people orient themselves to their environment."52

This just world orientation places certain expectations on the law as the key institution that possesses the power and authority to keep the world safe and secure. From this perspective, our need to believe that the world operates on principles of fairness influences how we evaluate law's efficacy in the provision of justice goals. It is then unsurprising that crisis events can so easily provoke fear and doubt if we are uncertain about our level of safety in the world. This "just" worldview is evident in the Twitter narrative produced through the rhetoric of fear in response to the Sydney Siege. Take for example these tweets:

Never have I ever felt so much fear for Australia and its citizens. What is wrong with this world? \#MartinPlaceSeige \#sydneysiege \#terror ${ }^{53}$

The unfolding \#sydneysiege is another terrible incident in an ever growing world of fear .... ${ }^{54}$

The hostage situation in Sydney shocked many, ${ }^{55}$ and kick-started a fatalistic sensibility, with Australians suddenly realizing that the "chaos and danger that [previously] had been an ocean away were now all around us - it was here and no longer just over there." ${ }^{56}$ By relying on long-held beliefs about a just world that incorporate expectations surrounding dualities of safety and harm, freedom and control, protection and vulnerability, the rhetoric of fear "activates the deeply entrenched good-vs evil narrative" 57 which in the end serves to reinforce law's justice narrative.

In my analysis of the tweets during this siege, a reinforcement of the just worldview was evident within three distinct emotionally evaluative threat appraisals: (1) an appraisal that the event was personally relevant as it made users particularly vulnerable in the everyday world (what I have named referential vulnerability); (2) a significant empathetic appraisal of the incongruence of the situation that produces an almost corporeal narration of the event (what I have named empathetic incongruence); and (3) an appraisal of blame that is firmly grounded in anger. This section will now work through each emotive appraisal as reflected in the Twitter narratives.

\section{Referential vulnerability}

An individual makes a statement referentially that connects the situation to their own life, utilizing it to articulate expectations and ideas about certain aspects of their lives. ${ }^{58}$ It is through discussing crisis events or tragedy referentially that individuals imagine what it would be like to be in that situation, and they spontaneously use the event as a springboard for relating to personal, interpersonal, or communal attitudes and values. Sara Ahmed suggests that vulnerability can be 
described as "feelings of susceptibility and openness to attack" such that it involves a "particular kind of bodily relation to the world, in which openness itself is read as a site of potential danger." ${ }^{59}$ Along these lines, I applied referential vulnerability as a category representing a particular performative evaluation where the individual expresses a disruption to their familiar worldview and subsequently relates it to their personal experience. Tweets were therefore coded for referential vulnerability when statements suggested that in their everyday lives, users might be unable to protect themselves. ${ }^{60}$ The analysis showed a strong emerging narrative that scripted individuals as "vulnerable and in dire need of protection" in their everyday lives. ${ }^{61}$ The prism of fear through which the public viewed this event sharpened the focus on an already present perception of our everyday world as scary, unpredictable, and chaotic, and the tweets demonstrated a heavy reliance on the persuasive appeal of pathos, as an effective method for referentially communicating the significance that our just world was coming under threat. For example:

You can't even go buy chocolates for Christmas anymore without fear of being taken hostage by terrorists \#unbelievable \#sydneysiege ${ }^{62}$

Is it even safe to leave your home anymore? Can we as Australians walk freely down the street without the fear of terrorism? \#sydneysiege 63

This articulated vulnerability in everyday life is, as Nussbaum argues, "magnified by the tendency of the startle instinct to make us especially frightened of that which leaps out suddenly catching us unawares" ${ }^{24}$ and it was especially evident in tweets that showed that the banality of getting a morning coffee was now being corrupted by the fear of being in that very position:

Hope the \#sydneysiege ends peacefully but I fear the worst [Weary Face emoji] what sort of a world do we live in where you're not even safe having a coffee [Pensive Face emoji] ${ }^{65}$

What is the world coming to? You can't go to a cafe in peace anymore without fear that these evil barbarians will come and hold you hostage? \#SydneySiege ${ }^{66}$

They went for a hot chocolate or a coffee, world turned upside down. Hard to imagine, and too easy to imagine the fear \#sydneysiege \#Lindt ${ }^{67}$

It's stupid how nowadays we can't even go have coffee without having that fear of getting held hostage \#SydneySiege ${ }^{68}$ 
The cumulative impact of fear rhetoric is to reinforce society's consciousness of vulnerability, and "the more powerless we feel the more we are likely to find it difficult to resist the siren call of fear." " Indeed, "[f] ear is nourished by the idea of a disguised enemy," 70 and the pathos appeals concerning vulnerability become quite effective because they reinforce ideas such as: "we are all potential victims"; "random terrorism can erupt at any moment"; and indeed that "terrorists are lurking in public spaces ready to pounce." This is the essence of Aristotle's argument about the success of perpetual fear:

It follows therefore that fear is felt by those who believe something to be likely to happen to them, at the hands of particular persons, in a particular form, and at a particular time. ${ }^{71}$

The analysis of the tweets surrounding the Sydney Siege demonstrated that by facilitating the circulation of fear on Twitter, personhood had been recast as the vulnerable subject. ${ }^{72}$ More than this, contained within the emerging referential narrative was evidence of corporeal vulnerability borne through fear. As the event unfolded through the evening and night, the narrative turned to descriptions of how this experience of fear was impacting upon individuals in a personal way. As Ahmed argues, emotions are "spaces in which bodies and worlds meet and leak into each other," and in fear, "the world presses against the body." ${ }^{73}$ Individual Twitter users increasingly referentially expressed this "pressing of emotion on their bodies" through an acknowledgment of the physiological impact of such a distressing situation on their ability to sleep:

I can't sleep. Not when one of the worst nightmares is unravelling in a place that I call home and when others fear sleeping \#sydneysiege ${ }^{74}$

I don't want to go to sleep for fear of what I may wake up to tomorrow. I pray this ends without a soul hurt \#sydneysiege \#PrayForSydney ${ }^{75}$

How anyone can sleep right now is beyond me. I'm staying wide awake until justice is served \#aslongasittakes \#sydneysiege ${ }^{76}$

Just woke up randomly and checked my newsfeed to see \#sydneysiege is still going on, all of a sudden, a massive fear has hit me like a truck [Loudly Crying Face emoji] ${ }^{77}$

The referential framing of vulnerability as associated with personhood in this way continues to affirm the just world narrative that is so prevalent within the 
rhetoric of fear. It proceeds from taken-for-granted assumptions that we live in a world where the ultimate goal of law is to prevent the invasion of terror and crime in our everyday, and we are seemingly so fearful of any threat to that security and safety that we propagate a self-fulfilling prophetic reproduction of fearful communication.

In particular, once images of escaping hostages started being reproduced, Twitter users began to narrate the physiological impact of their emotional responses:

Feel sick watching the coverage of the \#sydneysiege on @Channel7 Three people just ran out and you could FEEL the fear they possessed. $^{78}$

Just looking at the girls running out in fear like that.. my heart is thumping. They must've been terrified! [Crying Face emoji] \#sydneysiege ${ }^{79}$

The way she latches on to the police officer gives me chills. I haven't seen someone with that much fear in a very long time \#sydneysiege ${ }^{80}$

I feel sick. I pray for safety to all involved. I pray that the perpetrator be brought to justice. \#PrayForSydney \#sydneysiege ${ }^{81}$

Seeing the fear in the faces of the hostages who escaped makes my heart sink \#sydneysiege ${ }^{82}$

Can't imagine the fear they must be going through! It got me the goose bombs! Prayers for all in this dreadful situation \#sydneysiege 83

Individuals spoke of "feeling the palpable fear" through the visuals of the hostages escaping. As they tried to imagine how they would have been feeling in the same situation, they experienced actual physical responses. Their descriptions utilized emotive language that expressed the corporeal impact of fear and vulnerability: "heartbreaking," "heart wrenching," "overwhelming," "haunting," "absolutely chilling," "confronting," "unthinkable," "horrifying," "my heart hurts." Below are some further examples:

The look on the woman's face that ran out still gives me chills. You could almost feel the fear she's experiencing. \#sydneysiege ${ }^{84}$

The look of pure fear on the faces of those escaping employees is putting a gulp in my throat \#sydneysiege ${ }^{85}$ 
I can't watch the video of those two girls running from the building. The terror and fear in their eyes is so confronting [Crying Face emoji] \#sydneysiege ${ }^{86}$

\section{Empathetic incongruence ${ }^{87}$}

Contributing even more to this referential vulnerability was the way in which individuals made significant empathetic appraisals concerning the incongruent nature of the hostage crisis. Because it was a circumstance that is not at all consistent with the just worldview that circulates within everyday legal consciousness in Australia, individuals expressed their inability to comprehend this crisis:

Cannot begin to imagine the terror and fear in the minds of those held hostage. Praying this will end peacefully \#SydneySiege \#MartinPlace ${ }^{88}$

Can't begin to imagine the terror and fear in the minds of the hostages held in \#SydneySiege \#MartinPlace. Praying and hoping they'll be ok ${ }^{89}$

This was a common refrain in the tweet narrative with one in every five comments in this category referencing the inability to "imagine" what the hostages would be experiencing. ${ }^{90}$ Empathetically incongruent statements were thus coded against claims about the importance of the situation and its tragic, devastating and horrifying nature, and were related to ideals about public safety and security.

As mentioned above, an individual will often relate stories to their own lives or to the lives of other real people, ${ }^{91}$ and in turn respond emotionally ${ }^{92}$ to them through their appraisal of empathetic incongruence. In using repetitious statements such as "I can't imagine the fear," or "the fear on her face is terrifying," combined with emotive language that particularly focus on the horrific and inconceivable nature of this event, these tweets provoked an emotional identification with the victims. Take for example, these two tweets:

I can't imagine the fear going on in Sydney how terribly awful I feel for those innocent people taken hostage \#SydneySiege pray for them [Person With Folded Hands emoji $\times 3]^{93}$

I'm shaking right now, how could this happen? \#sydneysiege They were innocent people! [Confounded Face emoji] [Crying Face emoji] [Tired Face emoji] I pray that justice will be served to that man. ${ }^{94}$

By describing their attempt to imagine themselves in such a situation, individuals became highly emotionalized spectators of the distant suffering of the victims. 
But more than this, the individualized impassioned tweets become part of the empathetic imagination expressed by the collective. This in turn, has enormous normative significance for law, which is "an expression and satisfaction of emotions." 95 Indeed, Robert Solomon argues that without an "empathetic perspective, there can be no adequate conception of justice or law," 96 and certainly collective narratives that emerge on Twitter have the potential to define, rationalize and shape expectations of law.

In the analysis, it was clear that as individuals responded emotively to the Sydney Siege, the emerging narrative corroborated a "just" worldview whereby the protection of innocence is favored as one key goal of justice. This is evident in the following tweets where individuals deploy the good versus evil narrative to emotively assign innocence to the victims in contradistinction to the guilt of the perpetrator:

$16+$ hours of fear placed on innocent people who were just going about their daily lives ... Praying they escape unharmed \#sydneysiege ${ }^{97}$

It's a tragedy that three people were killed in the \#SydneySiege, two completely innocent. We need to know HOW they died. They deserve justice ${ }^{98}$

Shedding tears again for people I don't know. Innocent victims who died in fear \#sydneysiege ${ }^{99}$

In this narrative, innocent people have been thrust into fearful situations that they do not deserve, nor should have to endure under the protection of the law in their "daily lives." The proliferation of this narrative and the concept of the "innocent victim," has significant persuasive appeal because it perpetuates the narrative of a collective innocent and threatened "us" in relation to a malevolent and destructive "them," which works to fortify a just worldview. The tweets collectively work to align the audience emotionally with a shared attribution of evil, or guilt, or terrorism, as the "other" that is endangering what is "ours."100

If a single person dies in this siege I fear Australia will never be the same \#sydneysiege ${ }^{101}$

Why do I fear that the \#sydneysiege has already scarred our nation forever? \#prayforsydney ${ }^{102}$

This evil other threatens to diminish and destroy what "we" so dearly possess and value: our legitimate "just" world. In this way, the rhetoric of fear manifested in collective statements of either referential vulnerability or empathetic incongruence, invites 
the adoption of the "us $\mathrm{v}$ them" mentality by persuasively working on our emotions. ${ }^{103}$ In emotively articulating the cumulative experience of fear during this time, the Twitter narrative contributes to a shared expectation and assumption around law's role as protector, and in combination, the rhetoric of fear and the expression of emotion on Twitter, thus work through this othering to reinforce a justice worldview. Interestingly, in times of crisis, emotions related to this othering, are cultivated and recirculated by "recurrent [...] polemics, rationalities" and stories that often turn the tide of public comment into a "blaming game,"104 and this connects with the third emotive appraisal that is tied to the fortification of law's justice narrative.

\section{The blame game - critique of law}

Becoming a collective "us" means "developing a certain rage against these illegitimate others [...]"105 and it is exactly the fragility and vulnerability of our just world that provokes the conflation of law and justice within the public imagination, which in turn provokes a questioning of the legitimacy of the law, and its ability to cope with threatening crisis events. The rhetoric of fear manifests itself in a widespread perception of powerlessness, and our fears become expressed as complaint or critique not only about those who might be responsible, but also about those whom may have had the power to stand against it, or prevent it from happening in the first place.

Tweets were thus coded for statements that attributed blame and responsibility for the incongruent, harmful and threatening event. In many instances politicians or judges were seen to be at fault:

At least we are blaming the justice system now. So let's go bash some judges. They wear funny headwear. Don't ride with judges. \#sydneysiege ${ }^{106}$

Yet, primarily the criticism was leveled at the institution or system of "justice" more generally. ${ }^{107}$ To attribute blame on the justice system is a familiar framing of events within a retributive context that provokes outrage and ire when the "evil others" do not seem to "get what they deserve," or have been let loose to perpetrate their crimes: ${ }^{108}$

You know who's at fault for this whole Sydney Siege. Our justice system. That man should not have been walking the streets \#sydneysiege ${ }^{109}$

The justice system has failed two people miserably. No amount of words that can now bring comfort to... \#sydneysiege ${ }^{110}$

\#sydneysiege Tragedy this morning. Two innocent lives lost. Can't help but feel that justice system in Australia is not good enough. ${ }^{111}$ 
The typical and repetitive catch cry that "the justice system has failed" comes from an innate desire to hold individuals responsible for their actions, and it forms part of the "just" worldview that persists in public discourse. It feeds into what I have previously argued is an instinctive retributive public imaginary that contains a strong belief that the function and promise of law is actually to provide justice. ${ }^{112}$ Indeed, many of the tweets fuel criticism of law's claim to facilitate justice by a reference to what is lacking. Take for example these tweets that demonstrate a common negative collocation of ineffective law and an absent justice:

\#sydneysiege highlights how inadequate criminal justice system in dealing with the criminals. Man with multiple criminal charges in society $^{113}$

The Australian justice system has failed the victims of the \#sydneysiege. It's ridiculous to think that Haron Monis was allowed to walk free $^{114}$

As the Sydney Siege continued throughout the day, more details about the gunman and his legal history surfaced. Information circulated that Monis had been "the subject of many law enforcement and security investigations and assessments over the period of his residence in Australia," and in particular that he had been granted "bail for serious violent offences at the time of the siege." 115 In response to this information, the narrative appearing in the tweets increasingly articulated that because the law hasn't done its job properly (i.e., remanded the offender so that he is no threat to society), then there is a complete failure of the justice system.

How come this headcase was wandering around in society? How did he have a gun? Yet another fail for the justice system. \#sydneysiege ${ }^{116}$

Why was this moron out on bail in the first place?? A complete and total failure of the justice system! \#SydneySiege $\mathrm{e}^{117}$

The justice system has failed this country again, how was this $f^{*}$ cken dog to live freely in this country!?!? What a joke! \#sydneysiege ${ }^{118}$

The implied message of this repetitious narrative was that this one event is an horrific example of injustice proliferating within our legal system - that if the law actually dealt with offenders effectively then there would not be such a threat to our everyday existence, and we could live without fear. 
What these tweets of emotional critique demonstrate, is a legitimation of a just worldview where law is expected to consistently and faithfully achieve "justice," and that it is the failure of law's procedure and implementation that jeopardizes the achievement of justice as the primary goal of law:

Incredibly sad to hear two hostages lost their lives. May your deaths not have been in vain. Overhaul the justice system. \#sydneysiege ${ }^{119}$

Why was a known murderer and rapist walking free among us? Our flawed justice system allowed \#Sydneysiege to happen. We need reform \#auspol ${ }^{120}$

Of course in the days following the siege, there was expansive public debate over the merits of bail law reforms (which contributed to the joint state/federal government review), and this became a huge part of the continuing Twitter narrative within the hashtag Sydney Siege. While, an analysis of this ongoing attribution of blame to the bail system, and especially its impact on law's justice narrative, is beyond the scope of this article, the next section describes the second narrative or story arc that developed over the course of those two days: that is, the recognition of the constructed nature (and potential negative impact) of fear mongering and the active desire to resist it.

\section{Fear mongering and resistance}

As discussed above, the Twitter narrative produced over the two days of this hostage crisis, reflected in many ways an existing rhetoric of fear that traded on emotional expectations of law and justice. Yet, so much of the Twitter conversation showed a defiant determination to resist the temptation of fear mongering perpetuated by mass media:

\#Sydneysiege; stop spreading fear and hatred, instead pray for all to be solved quickly with no harm to any of the hostage. ${ }^{121}$

Screw people who try to terrorise us into frenzy of fear and hatred. You will not affect us or our lives. We choose how we live \#sydneysiege ${ }^{122}$

In fact, some blame for fear mongering was placed on politicians:

I just wish I could see past the way politicians use a tragic incident like this to create fear and spew hyperbolic crap \#sydneysiege ${ }^{123}$ 
\#sydneysiege leaders should provide comfort and solace during times of uncertainty. Why did @TonyAbbottMHR choose to heighten fear and terror? ${ }^{124}$

However, over $50 \%$ of all tweets coded critical were directed at mass media. It was clear that the emotion of anger was used within this particular hashtag as a mechanism for collectively expressing considerable critique about, and resistance to, the constructed nature of news reporting, and on the way these constructions have the power to impact perceptions, and manipulate "reality."

Media coverage of the \#sydneysiege has been abysmal. Speculation, bigotry and fear-mongering abound; shameful and utterly irresponsible. $^{125}$

Spread fact, not fear, or "good headlines" \#sydneysiege ${ }^{126}$

Speculation only spreads unnecessary fear! Some shocking clickbaiting and inaccurate reporting from Australian media today. \#sydneysiege 127 $^{127}$

By ascribing manipulative intent to the production of news, the tweets actively challenged the message that news reports comprise a truthful repository of facts, and they began to produce a story of resistance - using the concepts of unity and identity. Sydneysiders and Australians used tweets that promoted nationhood and local identity as the driving force toward unification in standing against fear. Even the lyrics of John Farnham's very Australian "You're the Voice" were appropriated for this purpose encouraging sydneysiders to not sit silently, nor live in fear.

Today my beautiful city weeps, even as we stand as one. We won't cower to fear or hate. We're stronger than that! \#sydneysiege ${ }^{128}$

Stay strong Sydney, we cannot let this stop us in our tracks and live in fear \#sydneysiege \#PrayersForSydney ${ }^{129}$

Amid the wealth of data to be analyzed about this public response to the media's manipulation of the rhetoric of fear, what I found most intriguing about these tweets of resistance during this time was the utilization of "othering" as a mechanism for that resistance. That is, the reason most often articulated as the motivation to resist fear itself, was the recognition of the potential negative impacts of "othering."

Research conducted after 9/11 has shown that "in times of heightened fear and anxiety, stereotypes are exacerbated, identity with one's own group (people we 
perceive to be like ourselves) [is] increased [and] suspicion of other groups is heightened, [as] we hold tightly to familiar/default scenarios." 130 The cultivation of the "us $\mathrm{v}$ them" mentality then, as an invocation of the power of law within the rhetoric of fear, provides the "means by which inclusion and exclusion takes place." ${ }^{\text {"131 }}$ The "other" becomes a racialized image of threat, which is "criminalized and stigmatized"132 and preconceived notions and stereotypes play a role in how individuals will perceive the situation. Unfortunately, one of the nastier aspects to the pathos displayed within this Twitter narrative was the anger and disgust expressed towards Islam and to members of the Muslim community. Reading through the tweets as I undertook the analysis, this racialization of the threat was overwhelmingly strong, as evidenced by just these two examples:

It's time for the world to denounce sharia law and the savages who support it. GET OUT OF OUR COUNTRY! \#sydneysiege \#NoAmnesty ${ }^{133}$

Wherever in the world \#Islam goes, mayhem, chaos, fear, terror, death and destruction always follow... \#sydneysiege \#lindtcafe ${ }^{134}$

At the same time, while this utilization of othering to express hatred and accusation was so prominent in the hashtag, it was also encouraging to read a divergent concern about the impact of such a communication of hatred. ${ }^{135}$ One particular story arc that developed within the Twitter narrative was the deep concern that cultural bigotry fueled by the hostage crisis might actually heighten emotional responses to the point of creating its own harm - in the form of a backlash against Muslim Australians:

I'm terrified and appalled of how much hate, racism and bigotry I see all over social media. I fear for all our Muslim citizens ;-( \#sydneysiege ${ }^{136}$

I fear for the hostages. I fear for the backlash by an angry and often ignorant public just as much. \#SydneySiege ${ }^{137}$

To all Muslims in Australia stay safe and protect yourself. I cannot imagine the fear you will get in our streets. $x x$ \#sydneysiege ${ }^{138}$

These tweets are an example of how the emotive expression of fear can perpetuate "otherness" associated with racial and cultural difference, which is then persuasively deployed as either hate or sympathy. For this article, I have focused the analysis on the use of othering as a way to promote solidarity and invoke resistance, evidenced particularly in one strong narrative arc. In this narrative, Muslims were framed as vulnerable "outsiders" in need of protection, and so before long a hashtag 
"social movement" was borne. Thousands of individuals adopted the \#illridewithyou hashtag to offer practical support by riding on public transport with Muslims who might be intimidated or apprehensive to travel alone. This "organic and spontaneous social media campaign gained momentum quickly." ${ }^{139}$ There were 40,000 tweets using the hashtag \#Illridewithyou in just two hours and within a day over 900,000 tweets using the hashtag had been posted as it trended globally. ${ }^{140}$

As an "exercise in viral empathy,"141 the \#illridewithyou campaign was undoubtedly positive. Despite some critics claiming that \#illridewithyou was "patronising, and a shallow and ineffective attempt to combat the deeper issues of discrimination, racism and Islamophobia,"142 \#illridewithyou did gain widespread attention because it actively sought to change the tone of the public conversation concerning the rhetoric of fear and make an impact on the emotional experience of fear caused by this event.

However, without denigrating or denying the positive effects of the campaign on a public experience of fear, I argue that this practical and symbolic resistance of the rhetoric of fear paradoxically represented a show of support and solidarity with Australian Muslims, and also a fragmentation of trust in the law to protect a portion of our community. The distrust and uncertainty was so great, that citizens used the virtual environment of Twitter as an outlet for social activism. Interestingly, the desire for individuals to take matters into their own hands ${ }^{143}$ and enact their own version of protective justice, was heightened by the very rhetoric of fear that some were trying to resist. ${ }^{144}$

Although it was heartwarming and encouraging to read comments that actively sought to persuade others to contest the encumbering effects of the rhetoric of fear, ironically this campaign nevertheless pointed to an underlying concern (whether substantiated or not) that some citizens may actually be vulnerable to attack, and demonstrated that individuals can be mobilized into action (both positive and negative) for the purposes of filling a perceived vacuum in law's security and protection. $^{145}$

\section{CONCLUSIONS}

The \#illridewithyou narrative that was occurring in tandem with the \#sydneysiege narrative serves as a practical illustration of emotional jurisprudence at work. Through the articulation of emotion - fear, anger, vulnerability and compassion individuals contributed to a collective emotional critique of law's capability to provide the protection it promises when it really counts. Public comments expressed in these Twitter narratives significantly deployed the persuasive appeal of pathos to provoke, engage, and animate imagination in relation to the maintenance of the "just" world in which they believe. The analysis of the tweets has shown that in the production of narrative surrounding this event, Twitter not only reflected anxieties 
around issues of law and justice but also functioned as the social agent through which tweets would either promote or challenge those very anxieties.

I have argued that social media facilitates the sharing of identity and community building through the telling and retelling of stories in relation to various issues and events. The Sydney Siege was an evocative event that depicted a possible fracturing of the just worldview to which we hold so tightly, and so the communal experience of fear, grief, anger, and compassion reflected emotional coping strategies that functioned as a stimulant to the acceptance and preservation of law's justice narrative. There is so much to glean about legal consciousness from social media. Living as we do in a hashtag world, it is important for us to recognize the nuanced complexities of social media and in particular the complicity of emotion and social media in public reflections of legal meaning.

\section{DISCLOSURE STATEMENT}

No potential conflict of interest was reported by the author.

Cornelius Puschmann, Axel Bruns, Merja Mahrt, Katrin Weller, and Jean Burgess, "Epilogue: Why Study Twitter?," in Twitter and Society, ed. Katrin Weller, Axel Bruns, Jean Burgess, Merja Mahrt, and Cornelius Puschmann (New York: Peter Lang, 2014), 425-32. Reported by the Public and News Professionals," The Conversation (December 16, 2014): 1.

History of a Political Idea (Oxford: Oxford University Press, 2004); and Judith Shklar, "The Liberalism of Fear," in Liberalism and the Moral Life, ed. Nancy Rosenblum (Cambridge, MA: Harvard University Press, 1989), 21-38.

throughout time and indeed becomes so strongly associated with certain topics that, on repetition, is joined with that term - as with an invisible hyphen and eventually the term fear is no longer stated but is simply implied. Examples from previous work include gangs, drugs, and [...] crime continues to be heavily associated with fear"; David Althiede,
"Terrorism and the Politics of Fear," Cultural Studies: Critical Methodologies 6, no. 4 (2006): 426. Furedi, Politics of Fear, 123

Ibid. Furedi argues that the frequent political message of "Not If - But When" regarding the threat of terrorism, "which assumes the form of a 'sensible' warning, directly encourages a sense of resignation concerning the inevitability of something bad happening"; 125. Martha Nussbaum, The New Religious Intolerance: Overcoming the Politics of Fear in an Anxious Age (Cambridge, MA: Harvard University Press, 2012), 20. beyond the objective fact of a distant danger and be transformed in the minds of the public into a pending, inevitable threat [... it is when the population is instilled with a] sense of dread of an unknown and yet-to-be-experienced collective harm"; Anne Aly and Lelia Green, "Fear, Anxiety and the State of Terror," Studies in Conflict and Terrorism 33 (2010): 269. See also Furedi, Politics of Fear, 133; and Robin, Fear: History of a Political Idea. 
17. Brian Massumi, "Fear (the Spectrum Said)," Positions 13, no. 1 (2005): 35.

18. Yvonne Tasker, "Television Crime Drama and Homeland Security: From Law \& Order to 'Terror TV,'" Cinema Journal 51, no. 4, (2012): 44-65. Social media is "a collective term for a group of internet-based applications that allow users to create, organise and distribute messages, pictures and audio-visual content"; Patrick Keyzer, Jane Johnston, Mark Pearson, Sharon Rodrick, and Anne Wallace, "The Courts and Social Media: What Do Judges and Court Workers Think?," Judicial Officers' Bulletin 25 (2013): 47. Or see the Oxford English Dictionary definition: "websites and applications that enable users to create and share content or to participate in social networking." Patrick George, Michael Byrne, Monica Allen, Stefanie Benson, Joseph Collins, James Mattson, Justine Munsie, Gabriella Rubagotti, and Gavin Stuart, Social Media and the Law (Sydney: LexisNexis Butterworths, 2014), 3.

21. Rachel Sullivan, "Live-Tweeting Terror: A Rhetorical Analysis of @HSMPress Twitter Updates during the 2013 Nairobi Hostage Crisis," Critical Studies on Terrorism 7, no 3 (2014): 423-24.

22. Pamela Schultz, "Trial by Tweet? Social Media Innovation or Degradation? The Future and Challenge of Change of Courts," Journal of Judicial Administration 22, no. 1 (2012): 30.

23. "Widespread use of social media has opened up possibilities for new modes of civic engagement as members of society 'interact with news, politics, crime, and other important social issues in meaningful ways'"; Michelle Rose and Richard Fox, "Public Engagement with the Criminal Justice System in the Age of Social Media," Oñati Socio-legal Series [online] 4, no. 4 (2014): 774. http://opo.iisj.net/ index.php/osls/article/view/325.

24. "Major news media outlets now [even] utilize Twitter feeds and Facebook posts to report the latest headlines and provide links to more in-depth news stories on their websites"; ibid.

25. Ibid., 778 .

26. Jane Johnston, "Courts' New Visibility 2.0," in The Courts and the Media: Challenges in the Era of Digital and Social Media, ed. Patrick Keyzer, Jane Johnston, and Mark Pearson (Canberra: Halstead, 2012): 57.

27. Theresa Sauter and Axel Bruns, "Tweeting the TV Event, Creating "Public Sphericules": Ad Hoc Engagement with SBS's Go Back To Where You Came From - Season 2," Media International Australia no. 15 (2014): 13.

28. Ibid., 13-14.
29. Johnston, "Courts' New Visibility 2.0," 57.

30. Ibid.

31. Ibid., 58.

32 . Alfred Hermida, "Citizen Journalists, the Media and the UK Terror Attacks," www.reportr.net/ 2007/07/02/citizen-journalists-the-media-andthe-uk-terror-attacks/ (2007) (accessed June 8, 2016).

33. The use of hashtags also allows for the creation of communities of people interested in the same topic.

34. Jane Stokes, How To Do Media and Cultural Studies, 2nd ed. (London: Sage, 2013), 144.

35. Cassandra Sharp, "'Represent a Murderer ... I'd Never do That!' How Students Use Stories to Link Ethical Development and Identity Construction," in The Ethics Project in Legal Education, ed. Michael Robertson, Lillian Corbin, Kieran Tranter, and Francesca Bartlett (London: Routledge, 2011), 33; Cassandra Sharp, "The 'Extreme Makeover' Effect of Law School: Students being Transformed by Stories," Texas Wesleyan Law Review 12, no. 1 (2005): 233.

36. Richard Sherwin, "Symposium: Introduction: Picturing Justice: Images of Law and Lawyers in the Visual Media," University of San Francisco Law Review 30 (Summer 1996): 891.

37. Terry Maroney, "Law and Emotion: A Proposed Taxonomy of an Emerging Field," Law and Human Behaviour 30 (2006): 122.

38. For example, Martha Nussbaum, Political Emotions: Why Love Matters for Justice (Cambridge, MA: Harvard University Press, 2013); Sara Ahmed, The Cultural Politics of Emotion (Edinburgh: Edinburgh University Press, 2004); and Maroney, "Law and Emotion."

39. The tweets selected for analysis were constrained to those with a time stamp within the critical two days of the siege.

40. Sanja Milivojevic and Alyce McGovern argue that this virtual ethnography allows the researcher to "understand the practices of the setting" and to observe behavior in a more natural environment; Sanja Milivojevic and Alyce McGovern, "The Death of Jill Meagher: Crime and Punishment on Social Media," International Journal for Crime, Justice and Social Democracy 3, no. 3 (2014): 25.

41. This number was reached by using search criteria that focused on the keywords "law," "justice," or "fear," and by further eliminating tweets that merely contained links, or other superfluous aspects. For further insight into the benefits of social media for criminology; and the pitfalls associated with it, see ibid. 
42. The Aristotelian method has been used by several scholars to understand the nature and impact of online network discourse during election campaigns; Tal Samuel-Azran, Moran Yarchi, and Gadi Wolfsfeld, "Aristotelian Rhetoric and Facebook Success in Israel's 2013 Election Campaign," Online Information Review 39, no. 2 (2015), 149-62; Jenny Bronstein, "Like Me! Analyzing the 2012 Presidential Candidates' Facebook Pages," Online Information Review 37, no. 2 (2013), 173-92; Kristin English, Kaye D. Sweetser, and Monica Ancu, "YouTube-ification of Political Talk: An Examination of Persuasion Appeals in Viral Video," American Behavioral Scientist 55, no. 6 (2011), 733-48. and pathos. Logos utilizes logic-based appeals; ethos emphasizes the speaker's credibility and trustworthiness; and pathos appeals to the audience's emotions. Interestingly, "the ethos strategy has long proved to be highly effective during [election] campaigns, since studies have found that communicators' characteristics and credibility strongly influence the perceived persuasiveness of their messages throughout election campaigns;" Azran et al., "Aristotelian Rhetoric and Facebook Success," 10. Ibid.

This will be defined and explained in the next section.

Some tweets contained more than one appraisal element, but the tweet was coded by the primary element.

Aly and Green, "Fear Anxiety and the State of Terror," 269.

David Blackall and Seth Tenkate, "Anti-terrorism, Climate Change and 'Dog Whistle' Journalism," Asia Pacific Media Educator 20 (2010): 207. Phillip Boulten SC, "Opening Speech - Debra Dawes' Cover-Up Exhibition," in David Blackall, Dog Whistle [video], YouTube, http://www.youtube.com/watch $? v=f d M o J y A K X v k$ fdMoJyAKXvk, fdMoJyAKXvk, quoted in Blackall and Tenkate, "Anti-terrorism, Climate Change," 207. See also Furedi, Politics of Fear; and Althiede, Terrorism and The Politics of Fear.

51. Melvin J. Lerner, The Belief in a Just World: A Fundamental Delusion (New York: Plenum, 1980).

2. Sandra L. Bloom, "Commentary: Reflections on the Desire for Revenge," Journal of Emotional Abuse 2, no. 4 (2001): 79.

@alicem1529, December 14, \#1422. Each tweet particular user identifier, date, and coded number allocated to it by the researchers.

Despite some early debate as to whether the situation classified as terrorism, or if Man Monis could be seen as a lone wolf terrorist, the event has been classified as a hostage situation - a "siege";

Michael Thawley and Blair Comley, Commonwealth of Australia 2015, Martin Place Siege: Joint Commonwealth - New South Wales Review (Canberra: NSW Government and Commonwealth Government, 2015). reproduced in this article will be referenced by the
Sue Veres Royal, "Fear, Rhetoric, and the 'Other,"' Race/Ethnicity: Multidisciplinary Global Contexts 4, no. 3 (Field Notes from the September 11 Moment, 2011): 406 (emphasis added).

Ibid., 407.

Tamar Liebes and Elihu Katz, The Export of Meaning: Cross-Cultural Readings of Dallas (Cambridge: Wiley, 1993), 103.

59. Ahmed, The Cultural Politics of Emotion (Edinburgh: Edinburgh University Press, 2004), 69.

60. Krista De Castella and Craig McGarty, "Two Leaders, Two Wars: A Psychological Analysis of Fear and Anger Content in Political Rhetoric about Terrorism," Analyses of Social Issues and Policy 11, no. 1 (2011): 186.

61. Julie Matthews, "Visual Culture and Critical Pedagogy in 'Terrorist Times,"' Discourse: Studies in the Cultural Politics of Education 26, no. 2 (2005): 204. @MicheleLeiby, December 14, \#1072.

63. @ItsMinaYo, December 14, \#1412.

64. Nussbaum, New Religious Intolerance, 27.

65. @AlexHatton10, December 14, \#1408.

Ahmed, Cultural Politics of Emotion, 2. She argues that "the body shrinks back from the world in the desire to avoid the object of fear. Fear involves shrinking back the body; it restricts the body's mobility precisely insofar as it seems to prepare the body for flight"; 69 (emphasis in original).

$74 @$ @hello_bp, December 15, \#655.

75. @megmckelvie, December 15, \#635.

76. @Abby_Gudgeon, December 15, \#758.

77.@20931027, December 15, \#640.

78. @MsPynk_8, December 14, \#1142.

79. @nurasirah, December 14, \#1059. 
80.|@carlyylalaa, December 14, \#1047.

81. @jonomount, December 14,\#1033.

82. @Jesss_5sos, December 14,\#1004.

83. @komalaujla, December 15, \#909.

84. @bieberisababeee, December 14,\#1016.

85.@@dom_1210, December 15, \#701.

86. @angaske_, December 15,\#757.

87. De Castella and McGarty deployed the category of "motivational incongruence" in the coding for their research on US political speeches. In their research "appraisal of motivational incongruence included statements of remorse, hatred, or disgust at terrorists or terrorist attacks, concerns for the future, and possible risks that the audience may face"; De Castella and McGarty, "Two Leaders, Two Wars," 186. For my project, I have adapted this coding as "empathetic incongruence" to connect with the way individuals were applying empathy to the incongruent situation of a hostage situation in Australia.

105. @themikeycole, December 14, \#1460. @NaraHodge, December 14, \#1454. Forty-four out 230 in the Fear category of Pathos. Liebes and Katz, Export of Meaning, 32. Ibid., 100. @KindaCraftyMom, December 14, \#1327. @RhiannaMariaa, December 15, \#241. Robert Solomon, "Justice v Vengeance: On Law and the Satisfaction of Emotion," in The Passions of Law, ed. Susan Bandes (New York: New York University Press, 1999), 127. Ibid. @Purp_Amethyst, December 15, \#588. @SydWalker, December 16, \#084. @traceylewis5, December 15, \#271. Matthews, "Visual Culture and Critical Pedagogy," 203.

@JodyMoller, December 14, \#1429. @fuzzylogic1206, December 14, \#1376. Ahmed, Cultural Politics of Emotion, 2. Matthews, "Visual Culture and Critical Pedagogy," 203.

6. @drdeathmont, December 15, \#222.

Thirty percent of all the tweets analyzed attributed blame on the justice system.

108. Cassandra Sharp, "Justice with a Vengeance Retributive Desire in Popular Imagination," in Law and Popular Culture: International Perspectives, ed. Michael Asimow (Cambridge, MA: Cambridge Scholars, 2014).

@MickWounds, December 15, \#160. @0001au, December 15, \#226.
111. @alannicolea, December 15, \#266.

112. Cassandra Sharp, "Finding Stories of Justice in the Art of Conversation: Ethnography in Cultural Legal Studies," in Cultural Legal Studies: Law's Popular Cultures and the Metamorphosis of Law, ed. Cassandra Sharp and Marett Leiboff (Abingdon: Routledge, 2015).

113. @FakeJourno, December 15, \#175.

114. @TheLocalGod, December 15, \#303.

115. Thawley and Comley, Commonwealth of Australia 2015, Martin Place Siege, vi. Monis "had been granted bail on charges of being an accessory before (and after) the murder of his estranged partner who died on 21 April 2013. He had also been granted bail in relation to charges for numerous sexual offences"; vi.

116. @lotus2955, December 15, \#228. sufianjaved, December 15, \#174 @tagsy23, December 15, \#388. @jean_virginia, December 15, \#402. @voiceofmanyAU, December 15, \#263. @JackySewell, December 14, \#1236. @Mariam_C, December 14,\#1095. @crido888, December 15, \#305. @DSP_AU, December 15, \#348. @Jordan_forward, December 15, \#203. @dee_antoinette, December 14, \#990. @sarahj_richo, December 14, \#1170. @Fiona_Archer, December 15, \#319. @morgan_penny, December 14, \#918. Veres Royal, "Fear, Rhetoric, and the 'Other,'" 408. Nick Lynn and Susan Lea, "'A Phantom Menace and the New Apartheid': The Social Construction of Asylum-Seekers," Discourse Society 24 (2003): 427. Ibid. @SweetFreedom29, December 14,\#1217. @ClimateMadness, December 14, \#1240. Further analysis is being conducted of the comparison between "fear mongering" tweets and Islamic supportive tweets and will form the basis for a subsequent article.

@TomasNemecek, December 15, \#813. @Gregulator614, December 14, \#1458. @arielnano, December 15, \#688.

Jennifer Doggett, "\#illridewithyou: More than Just a Hashtag," Crikey [health blog website] (January 16, 2015), http://blogs.crikey.com.au/croakey/2015/ 01/16/illridewithyou-more-than-just-a-hashtag/. Ibid.

1. Tasbeeh Herwees, "\#illridewithyou Is an Exercise in Viral Empathy," Good [website] (December 15, 2014), http://www.good.is/articles/illridewithyousydney-siege-muslims/./. 
"Hillidewithyou" For example, Eugenia Flynn, "What Happens When the Ride Is Over?," Vice [website] (December 16, 2014), http://www. vice.com/en_au/read/what-happens-when-theride-is-over/./.

"Social media provides opportunities for citizens to engage with criminal justice, and to feel ever empowered by their ability to influence others or enact justice as they see fit"; Rose and Fox, "Public Engagement with the Criminal Justice System," 787. "In an era of social media, we see [... activism] taking on many forms, including the direct participation of the audience or the public in attempting to enact some type of [...] justice. Whether social media use encourages a sort of cyber vigilantism is certainly a topic that requires further investigation $[\ldots]^{\prime \prime}$; ibid.

145.

This virtual space, absent of clear legal rules and responsibilities, is what lends itself to the rise in cyber vigilantism; Stephanie Juliano, "Superheroes, Bandits, and Cyber-nerds: Exploring the History and Contemporary Development of the Vigilante," Journal of International Commercial Law and Technology 7 , no. 1 (2012).

Cassandra Sharp is Associate Professor, Law School, Faculty of Law, Humanities and the Arts, University of Wollongong, and a member of the Legal Intersections Research Centre (LIRC). She thanks the Law, Literature and Humanities Association of Australasia for their invitation to present this paper at the annual conference in 2015, and in particular the support of Associate Professor Penny Crofts and Dr Honni Van Rijswijk. She also acknowledges and thanks Professor Nan Seuffert, Professor Elena Marchetti, Associate Professor Marett Leiboff, Karina Murray, and Margaret Bond for their comments made on previous drafts. 